УДК 612.75-092:616.12:618.3]-089

DOI 10.11603/24116-4944.2020.1.11492

\author{
${ }^{\circ}$ С. О. Сіромаха ${ }^{1,3}$, Ю. В. Давидова ${ }^{1,2}$, Н. І. Волкова ${ }^{1}$, В. В. Лазоришинець ${ }^{1}$

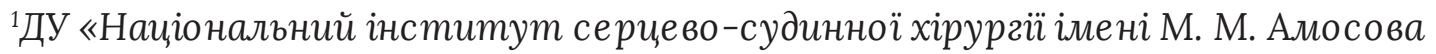 \\ НАМН України» \\ ${ }^{2}$ ДУ «Інститут педіатрї, акушерства та зінекологї ілені акаделіка О. М. Лук'янової \\ НАМН України» \\ ${ }^{3}$ Національний медичний університет ілені О. О. Богомольия
}

\title{
СИНДРОМ МАРФАНА ТА ВАГІТНІСТЬ
}

Мета дослідження - проведення аналізу сучасних рекомендацій та клінічних настанов, а також досвіду роботи національної мультидисциплінарної команди щодо медичного супроводу вагітних із синдромом Марфана (CM) 3 метою зменшення материнських та перинатальних втрат.

Матеріали та методи. 3 січня 2014 до червня 2020 року мультидисциплінарний колектив на базі клініки ДУ «Національний інститут серцево-судинної хірургії імені М. М. Амосова НАМН України» провів лікування 16 вагітних та породілей з аневризмою аорти. Спадкові захворювання грудної аорти з типовим фенотипом (синдром Марфана) спостерігалися у 3 вагітних. Серед них дві було з ГРАА у III триместрі та після пологів. Одна пацієнтка супроводжувалася мультидисциплінарною командою 3 14 тижнів вагітності до пологів. У 19 тижнів пацієнтці було виконано кардіохірургічне втручання 3 fetus in utero.

Результати дослідження та їх обговорення. У групі вагітних та породілей із патологією грудної аорти мала місце 1 материнська смерть (породілля із СМ та гострим розшаруванням аневризми аорти (ГРАА) на 40 тижні вагітності після екстреного кесаревого розтину та невідкладного втручання Бенталла-де-Боне на 7 добу після операції). Причиною смерті стала спонтанна гостра дисекція грудної аорти типу В із розривами низхідного відділу грудної аорти. Віддалені результати прослідковано в обох інших породілей - материнської смертності або «near-miss» не було. Перинатальних втрат не було. У статті обговорено патоморфологічні та патанатомічні фрактори, що впливають на зростання ризику виникнення ГРАА у вагітних із СМ. Представлено сучасні погляди на медичну допомогу вагітним із СМ, принципи первинної та вторинної профілактики великих кардіальних подій, у тому числі й небезпечного для життя ускладнення - гострої дисекції аорти. Обговорено акушерську та кардіохірургічну тактику у вагітних пацієнток із СМ, у тому числі й при гострій дисекції аорти. Розглянуто рекомендації щодо ведення пологів у пацієнток із СМ, проведення превентивної хірургії аорти, наведено клінічний випадок профрілактичної хірургії у вагітної із СМ з досвіду національної команди «акушерська кардіологія».

Висновки. Наявність синдрому Марфана значно збільшує материнські та перинатальні ризики та потребує ретельного мультидисциплінарного спостереження за вагітною та породіллею. Розвиток ГРАА у пацієнток із СМ під час вагітності - небезпечне для життя ускладнення, профрілактика якого потребує медикаментозного, а іноді й превентивного кардіохірургічного супроводу вагітної жінки.

Ключові слова: синдром Марфана; вагітність; кардіохірургія.

\section{СИНДРОМ МАРФАНА И БЕРЕМЕННОСТЬ}

Цель исследования - проведение анализа современных рекомендаций и клинических руководств, а также опыта работы национальной мультидисциплинарной команды по медицинскому сопровождению беременных с синдромом Марфрана (СМ) с целью уменьшения материнских и перинатальных потерь.

Материалы и методы. С января 2014 года по июнь 2020 мультидисциплинарный коллектив на базе клиники ГУ «НИССХ им. Н.М. Амосова НАМН Украины» провел лечение 16 беременных и рожениц с аневризмой аорты. Наследственные заболевания грудной аорты с типичным френотипом (синдром Марфана) наблюдались у 3 беременных. Среди них двое были с ОРАА в III триместре и после родов. Одна пациентка сопровождалась мультидисциплинарной командой с 14 недель беременности до родов. В 19 недель пациентке было выполнено кардиохирургическое вмешательство c fetus in utero.

Результаты исследования и их обсуждение. В группе беременных и рожениц с патологией грудной аорты наблюдалась 1 материнская смерть (роженица с СМ и ОРАА на 40 неделе беременности после экстренного кесарева сечения и неотложного вмешательства Бенталла-де-Боне на 7 сутки после операции). Причиной смерти стала спонтанная острая диссекция грудной аорты типа В с разрывами нисходящего отдела грудной аорты. Отдаленные результаты прослежены в обоих других рожениц - материнской смертности или «near-miss» не было. Перинатальных потерь не было. В статье обсуждены патоморфологические и патанатомические факторы, влияющие на рост риска возникновения ОРАA у беременных с СМ. Представлены современные взгляды на медицинскую помощь беременным с СМ, принципы первичной и вторичной профилактики больших кардиальных событий, в том числе и опасного для жизни осложнения - острой диссекции аорты. Обсуждены акушерская и кардиохирургическая тактика у беременных пациенток с СМ, в том числе и при острой диссекции аорты. Рассмотрены рекомендации по ведению родов у пациенток с СМ, проведение превентивной хирургии аорты, приведен клинический случай профилактической хирургии у беременной с СМ из опыта национальной команды «акушерская кардиология».

Выводы. Наличие синдрома Марфана значительно увеличивает материнские и перинатальные риски и требует тщательного мультидисциплинарного наблюдения за беременной и роженицей. Развитие ОРАА у пациенток с СМ во время беременности - угрожающее жизни осложнение, профилактика которого требует медикаментозного, а иногда и превентивного кардиохирургического сопровождения беременной женщины.

ключевые слова: синдром Марфана; беременность; кардиохирургия. 


\section{MARFAN SYNDROME AND PREGNANCY}

The aim of the study - to review current issues and clinical guidelines in medical care for pregnant women with Marfan syndrome, as well as the experience of the national multidisciplinary team to reduce maternal and perinatal losses.

Materials and Methods. Our pregnancy heart team from National Amosov Institute of Cardio-vascular Surgery took care on 16 pregnant women and parturients with aortic aneurysms from January 2014 to June 2020. Hereditary diseases of the thoracic aorta with a typical phenotype (Marfan syndrome) were observed in 3 pregnant women. Among them - two were with AAD in the III trimester and in postpartum. One patient was observed by a multidisciplinary team from 14 weeks of gestation up to the delivery. Preventive cardiac surgery in 19 weeks of gestation with fetus in utero was performed.

Results and Discussion. In the group of pregnant women and parturients with thoracic aortic pathology, one maternal death was observed on the 7th day after cardiac surgery (parturient with MS and AAD at 40 weeks of gestation after emergency cesarean section and urgent Bentall de Bone intervention). The cause of death was spontaneous acute dissection of the thoracic aorta type $B$ with ruptures of the descending thoracic aorta. Long-term results were observed in both other mothers - there were not maternal mortality or "near-miss". There were no perinatal losses. In the article we discuss pathomorphological and pathoanatomical factors that affect the increased risk of AAD in pregnant women with MS. Current views on medical care for pregnant women with MS, the principles of primary and secondary prevention of major cardiac events, including a life-threatening complication - acute aortic dissection. Obstetric and cardiac surgery tactics in pregnant patients with MS, including AAD, are discussed. We talked over recommendations for delivery methods in patients with MS, indications for preventive aortic surgery, a clinical case of preventive surgery in pregnant women with MS from the experience of national pregnancy heart team.

Conclusions. The presence of Marfan syndrome significantly increases maternal and perinatal risks and requires careful multidisciplinary support of the pregnant woman and parturient. The development of AAD in patients with MS during pregnancy is a life-threatening complication, the prevention of which requires medical and sometimes preventive cardiac surgery for pregnant women.

Key words: Marfan syndrome; pregnancy; cardiac surgery.

ВстУп. Патологія грудної аорти у вагітних може розвинутись за наявності деяких уроджених вад серця (наприклад, двостулковий аортальний клапан, тетрада Фалло та коарктація аорти (КоА)), внаслідок впливу набутих етіологічних чинників (прееклампсія, гіпертонічна хвороба, атеросклеротичні зміни в стінці аорти, специфрічні захворювання тощо), а також як результат мутації певного гена (спадкові захворювання грудної аорти). Спадкові захворювання грудної аорти (СЗГА) належать до аортопатій із високим ризиком формування та розшарування аневризми грудної аорти та викликаних мутацією певного гена $[1,2,3]$. Найпоширенішим синдромом із групи спадкових захворювань грудної аорти, пов'язаним із мутацією гена FBN1 (кодує глікопротеїн фрібрилін-1), є синдром Марфана (СМ) [3]. Вперше був описаний Антуаном Марфраном, фрранцузьким педіатром, у 1896 році [4]. Пацієнти із синдромом Марфана мають мутацію в гені фрібриліну в хромосомі 15q21 [5]. Спадкується як автосомно-домінантний фенотип та характеризується такими проявами: з боку серцево-судинної системи: дилатація аорти на рівні синусів Вальсальви, схильність до розшарування та розриву аорти, пролапс мітрального клапана з регургітацією або без неї; пролапс трикуспідального клапана та розширення проксимального відділу легеневої артерії; з боку органів зору (короткозорість, вивих кришталика); з боку опорно-рухового апарату (непропорційно довгі кінцівки відносно тулуба, надмірна рухливість у суглобах, pectus excavatum, сколіоз) [6].

Поширеність синдрому становить 1:3000 - 1:5000 випадків. Діагностується СМ за наявності основних та допоміжних критеріїв [7].

Загальний ризик вагітної із синдромом Марфрана отримати розшарування аорти становить 3 \%. Розмір аорти є головним визначальним фрактором ризику, але навіть пацієнтки 3 коренем аорти <40 мм мають ризик розшарування близько $1 \%$. Цей ризик збільшується до $10 \%$ при діаметрі аорти >40 мм [8]. Ризик акушерських ускладнень також підвищується [6].
Втім, існуючі настанови щодо вагітності та синдрому Марфана ще не мають високого ступеня рекомендацій та достатнього рівня доказовості [6, 9]. Дослідження з цього питання (ROPAC) проводить міжнародна група експертів під егідою Європейського товариства кардіологів.

МЕТА ДОСЛІДЖЕНня - проведення аналізу сучасних рекомендацій та клінічних настанов, а також досвіду роботи національної мультидисциплінарної команди щодо медичного супроводу вагітних із синдромом Марфана з метою зменшення материнських та перинатальних втрат.

МАТЕРІАЛИ ТА МЕТОДИ. 3 січня 2014 до червня 2020 року мультидисциплінарний колектив (pregnancy heart team) на базі клініки ДУ «Національний інститут серцево-судинної хірургії імені М. М. Амосова НАМН України» (далі - HICCX ім. М. М. Амосова) провів лікування 16 вагітних та породілей з аневризмою аорти. Спадкові захворювання грудної аорти з типовим фенотипом (синдром Марфана) спостерігали у 3 вагітних. Пацієнток обстежували за локальним протоколом HICCX ім. М. М. Амосова з обов'язковим збором сімейного анамнезу захворювання аорти та історії розшарувань у родині, використанням загальноклінічних та інструментальних методів (електрокардіографія, ехокардіографрія, рентгенографрія, комп'ютерна томографрія (рис. 1) або МРТ в ангіорежимах) з урахуванням статусу пацієнтки (вагітна чи породілля) та екстреності випадку (табл. 1).

Тактика надання медичної допомоги при ГРАА була такою: першим етапом виконували екстрене родорозрішення шляхом кесаревого розтину, другим - невідкладне втручання на аорті. Оперативні втручання на ВА були виконані за методикою Бенталла-де-Боне, відповідно до попередніх розробок мультидисциплінарного колективу [10]. Під час штучного кровообігу та фрармако-холодової кардіоплегії виконували протезування аортального клапана та висхідної аорти з реімплантацією вічок коронарних артерій (рис. 2). 

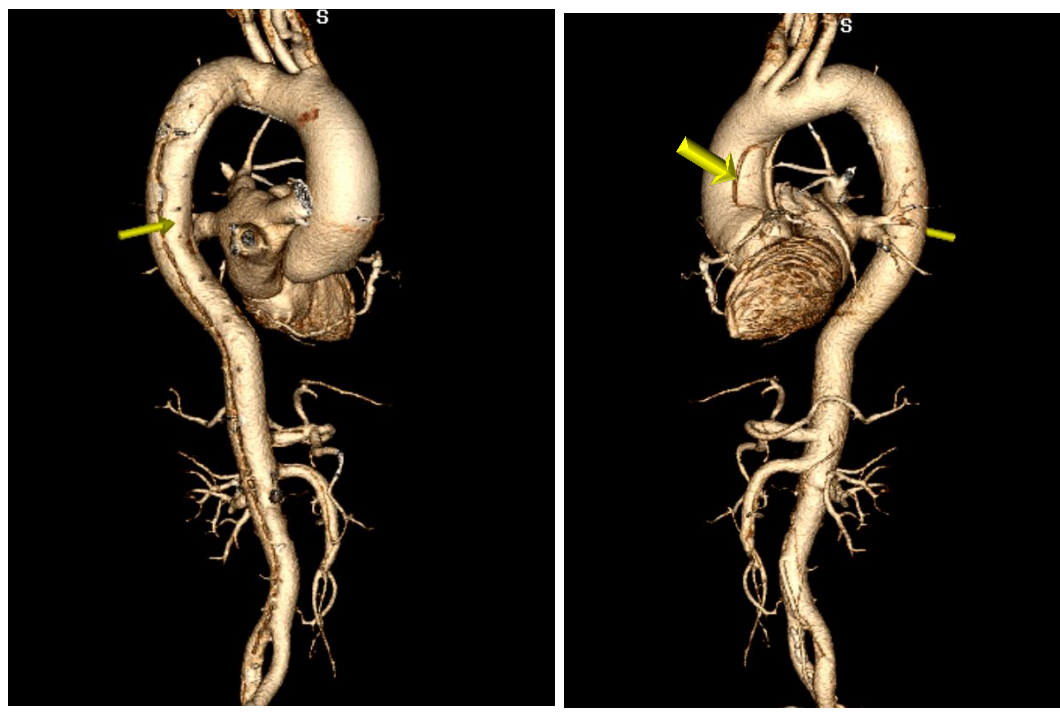

Рис. 1. Комп'ютерна томографрія в ангіорежимі грудної та черевної аорти. 3-D реконструкція. ГРАА типу А. Лінію розшарування позначено стрілками. Дані НІСCX ім. М. М. Амосова НАМН України.

Таблиця 1. Характеристика пацієнток та види їх мультидисциплінарного супроводу

\begin{tabular}{|c|l|c|l|c|c||}
\hline № & \multicolumn{1}{|c|}{ Ідентифікатор* } & Вік & \multicolumn{1}{|c|}{ Діагно3 } & Термін вагітності & \multicolumn{1}{|c|}{ Вид втручання } \\
\hline 1 & С (600-2014) & 24 & ГРАА типу А, СМ & $\begin{array}{l}\text { 1) екстрений кесаревий розтин } \\
\text { 2) невідкладне Бенталла-де-Боне }\end{array}$ \\
\hline 2 & Ю (1599-2015) & 22 & $\begin{array}{l}\text { Aневризма кореня Ao. } \\
\text { СМ }\end{array}$ & $\begin{array}{l}\text { 1) планове втручання Бенталла-де- } \\
\text { Боне 3 fetus in utero } \\
\text { 2) Планове родорозрішення в } \\
\text { терміні 38 тиж. }\end{array}$ \\
\hline 3 & К (1207-2019) & 36 & $\begin{array}{l}\text { ГРАА типу А. СМ. Анев- } \\
\text { ризма ВА с/п кесаревого } \\
\text { розтину }\end{array}$ & $\begin{array}{l}\text { породілля } \\
\text { Боне 3 реконструкцією напівдуги } \\
\text { клапановмісним кондуїтом }\end{array}$ \\
\hline
\end{tabular}

Примітки: 1) *Ідентисрікатор - номер карти стаціонарного пацієнта та рік.

2) СМ - синдром Марфана; ГРАА - гостра розшаровуюча аневризма аорти; ВА - висхідна аорта.
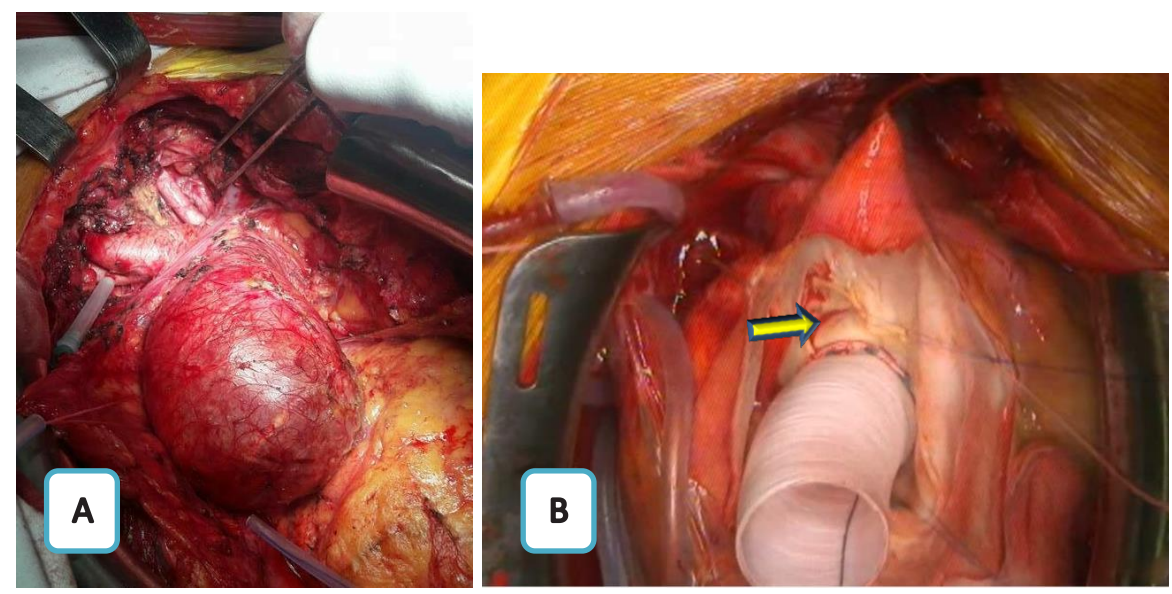

Рис. 2. Гостра розшаровуюча аневризма аорти. А. Зовнішній вигляд аневризми ВА. В. Етап хірургічної корекції. Аорта розсічена поздовжньо. Видно зону розшарування інтими (стрілка) та сформований дистальний анастомоз клапановмісного кондуїту. Дані НІССХ ім. М. М. Амосова НАМН України.

РЕЗУЛЬТАТИ ДОСЛІДЖЕННЯ ТА ЇХ ОБГОВОРЕНнЯ. У групі вагітних та породілей із патологією грудної аорти спостерігали 1 материнську смерть (породілля із СМ та ГРАА на 40 тижні вагітності після екстреного кесаревого розтину та невідкладного втручання Бенталла-де-Боне на 7 добу після операції). 
Причиною смерті стала спонтанна гостра дисекція грудної аорти типу В із розривами низхідного відділу грудної аорти в зоні лівої підключичної артерії та на рівні діафрагми.

Віддалені результати прослідковано в обох інших породілей - материнської смертності або «near-miss» не було.

Окремо варто описати клінічний випадок медичного супроводу вагітної з СМ, якій під час II триместру гестації було проведено профрілактичну хірургію аорти 3 «fetus in utero». У пацієнтки Ю. (1599-2015) було встановлено діагноз аневризми кореня та ВА у поєднанні з СМ на 14 тижні вагітності. Жінка одразу потрапила під мультидисциплінарний нагляд нашої pregnancy heart team. У зв'язку із значною аневризмою кореня аорти (на рівні синусів Вальсальви - 62 мм) та ВА (45 мм), а також наявністю спадкового захворювання грудної аорти (CM) було вирішено провести превентивну корекцію аортопатії у найбезпечніший для плода період - 16-23 тижні гестації. Кардіохірургічне втручання - операція Бенталла-де-Боне - зі штучним кровообігом (ШК) було виконано у 19 тижнів вагітності на «лагідних» параметрах ШК та з фетальним моніторингом, відповідно до запатентованої методики [11]. Медичний супровід мультидисциплінарним колективом проведено без летальності та ускладнень з боку матері або плода - вагітну було розроджено в терміні 38 тижнів гестації, віддалені результати задовільні. Пацієнтка завагітніла повторно та народила здорову дитину через 4 роки після втручання.

Переважаючим компонентом позаклітинного матриксу є один із глікопротеїнів, колаген, до складу матриксу входять еластин, фрібрин, фрібронектин, мінерали та інші компоненти. Таким чином, фрібрилін-1 - це необхідний елемент фрормування та збереження структури й цілісності еластичних волокон. Особливе значення позаклітинний матрикс набуває в структурі аорти, великих артерій, клапанного апарату серця, кісткової тканини. Порушення в кодуванні фрібриліну-1 (спостерігається саме при СМ) призводить до молекулярних змін, що спричинюють фррагментацію волокон сполучної тканини і призводять до зниження її еластичності та схильності до надриву. Саме через цю нееластичність стінка аорти не здатна протистояти силі, що виникає внаслідок артеріального тиску, що призводить до утворення аортопатій, характерних для синдрому Марфана [12]. Особливо актуальним це питання постає під час вагітності, коли навантаження на серцево-судинну систему значно зростає. Об'єм крові збільшується на 1000-1500 мл, а це приблизно більше на 30-50 \% ОЦК [13]. Про зміни в інтимі та медії аортальної стінки під час вагітності свідчать також патоморфологічні дослідження. Причому дослідження $є$ досить контраверсивними - одні автори стверджують, що інтима гіперплазується [14], інші - навпаки демонструють результати досліджень, в яких інтима значно гіпоплазується під час вагітності, і її площа перетину стає найменшою на момент пологів [15]. Проте електронна мікроскопія виявляє, що площа поперечного перерізу та мінімальний і максимальний діаметр ендотеліальних клітин інтими значно та поступово зменшуються під час вагітності [15].

Десрект структури сполучної тканини, що спостерігається у пацієнтів із синдромом Марфана, може сприяти розширенню кореня аорти та розшаруванню аорти. Виявлено такі аномальні біофізичні властивості аорти у пацієнтів із синдромом Марфана навіть у аортах нормального розміру за допомогою магнітно-резонансного картування [16]. У таких пацієнтів зменшується розтяжність аорти та збільшується швидкість хвилі вигнання порівняно зі здоровими пацієнтами. Це дослідження свідчить про додаткове навантаження на стінку аорти у пацієнтів із синдромом Марфана, що може сприяти розшаруванню під час вагітності [17].

$€$ також додаткові фрактори, що можуть спровокувати розвиток аневризми та її розшарування. Вагітна матка спричиняє значне стиснення аорти та клубових артерій, особливо в положенні лежачи. Це може підвищувати зовнішній опір артеріального дерева нижньої половини тулуба, а одночасне збільшення серцевого викиду крові у ВА може додатково провокувати розшарування. Специсрічні рецептори для естрогену і прогестерону збільшуються протягом всієї вагітності, а потім повертаються до «довагітного» рівня. Ці гормональні есректи призводять до розщеплення ретикулінових сполук, зменшення кількості кислотних мукополісахаридів та сприяють втраті нормального скорочення еластичних волокон [18]. 3 огляду на вищевикладене, зрозуміло, чому саме пацієнтки із СМ перебувають у зоні найвищого ризику розвитку аневризми аорти та ії розшарування.

Основними життєзагрозливими ускладненнями з боку серцево-судинної системи у пацієнтів із СМ $є$ аневризмоутворення та гостра дисекція аорти. Серцево-судинні захворювання є найпоширенішою причиною смерті пацієнтів із СМ. Вже $61 \%$ немовлят та дітей мають аномалії розвитку серця, як правило, мітрального клапана [19]. Дилатація кореня аорти розвивається на ранніх етапах СМ і спостерігається у $35 \%$ осіб у віці до 5 років та у 68-80 \% осіб віком до 19 років [20]. Частота дисекції аорти типу А складає $15 \%$, середній вік розшарування - 35 років, типу В - $4 \%$ у віці 36 років. Середній діаметр аорти на момент розшарування при типі $A-7,2 \mathrm{~cm}$.

Якщо поперечний розмір аорти становить 40-45 мм, слід враховувати й інші фрактори, такі як сімейний анамнез розшарування та швидкість зростання діаметра аорти. $€$ також ризик дистального розшарування аорти та розшарування інших судин. 3 цієї причини навіть після хірургічної корекції кореня аорти пацієнти залишаються в зоні ризику подальших ускладнень. Зростання діаметра аорти під час вагітності у пацієнтів із СМ є питанням спірним: деякі дослідження не демонстрували значного зростання [21], а інші демонструють зростання діаметра аорти $>3$ мм із частковою його регресією після пологів [22]. Інші важливі серцеві ускладнення включають прогресуючу мітральну регургітацію внаслідок пролапсу мітрального клапана, появу аритмій та серцеву недостатність внаслідок дисфрункції шлуночків.

Втім, існуючі настанови щодо вагітності та синдрому Марфана ще не мають високого ступеня рекомендацій та достатнього рівня доказовості (табл. 2) [6]. Дослідження з цього питання (ROPAC) проводить міжнародна група експертів під егідою Європейського товариства кардіологів.

На сьогодні консенсус експертів відносить аортопатію при СМ до II (Синдром Марфана без аневризми 
Таблиця 2. Рекомендації Європейського товариства кардіологів щодо медичного супроводу вагітності у пацієнток із синдромом Марфана

\begin{tabular}{|c|c|c|}
\hline Рекомендація & Клас & Рівень \\
\hline $\begin{array}{l}\text { Терапію бета-блокаторами протягом всієї вагітності має бути враховано у жінок із синдромом } \\
\text { Марфрана та іншими спадковими захворюваннями грудної аорти }\end{array}$ & Ila & C \\
\hline 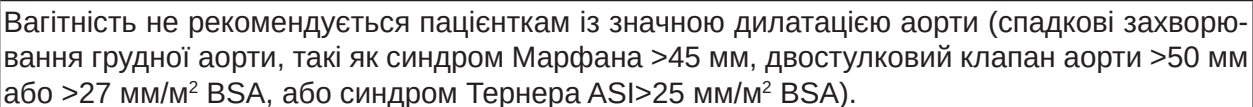 & III & C \\
\hline
\end{tabular}

Примітка. ASI - aortic size index - індекс розміру аорти, BSA - площа поверхні тіла.

Ао), III (аневризма аорти 40-45 mm при синдромі Марфрана) та навіть IV (аневризма аорти при синдромі Марфана >45 mm) класів кардіоваскулярного ризику за ВОO3 [6].

Залежно від вихідного діаметра аорти стан вагітних із СМ та патологією аорти слід контролювати за допомогою ехокардіографрії через рівні проміжки часу протягом всієї вагітності та раз на місяць протягом 12 місяців після пологів. У жінок із високим ризиком розшарування або зі значною дилатацією аорти моніторинг щомісяця $€$ обов'язковим, тоді як у жінок із низьким рівнем ризику, які мають лише незначно розширену аорту, видається доцільним моніторинг кожні 12 тижнів. При необхідності можна використовувати МРТ серця без контрасту. Вагітність повинна супроводжуватися мультидисциплінарною командою фрахівців. Рекомендовано суворий контроль AT, і при необхідності призначається безпечне для плода гіпотензивне лікування [6]. Задля запобігання виникненню гострого розшарування аорти під час вагітності важливим $€$ преконцепційне консультування жінок із СМ та їхня предгравідарна підготовка, в тому числі і проведення профрілактичного хірургічного втручання. Американський коледж кардіологів [23], а також і деякі інші дослідники цієї проблеми [18] рекомендують жінкам із СМ, які планують вагітність, пройти просрілактичну хірургічну корекцію аорти, якщо діаметр кореня аорти перевищує 40 мм (рівень рекомендації С). Канадські та європейські рекомендації пропонують жінкам, які планують вагітність, пройти профілактичну хірургічну корекцію аорти, якщо діаметр кореня аорти перевищує 45 мм [8].

Важливим $є$ питання тактики медичного супроводу вагітної із СМ та некоригованою патологією аорти. Рекомендації Європейського товариства кардіологів щодо інтервенцій під час вагітності при аортопатіях такі [6]:

Якщо дилатація аорти прогресує під час вагітності, та плід ще не життєздатний, варто розглянути хірургічне лікування 3 fetus in utero.

Якщо плідє життєздатним, рекомендується проведення кесаревого розтину з наступною операцією на аорті. Кесарів розтин слід проводити в стаціонарі, в якому $є$ кардіоторакальна хірургія та реанімація новонароджених.

У пацієнток із гострими аортальними станами під час вагітності лікування включає медикаментозну терапію, хірургічні та ендоваскулярні втручання.

Розшарування типу А за Стендфордською класифрікацією - це ургентна ситуація, що потребує швидких злагоджених дій pregnancy heart team.

У разі неускладненої дисекції аорти типу В рекомендовано консервативне лікування з суворим контролем АТ з використанням препаратів, дозволених під час вагітності.
Основною метою медичного супроводу пацієнток 3 аневризмою аорти під час пологів $€$ зменшення серцевосудинного стресу. Якщо жінка приймає бета-блокатори під час вагітності, їх слід продовжувати в післяпологовому періоді. Рекомендації щодо пологів для жінок із СМ базуються на діаметрі кореня аорти.

Вагітним з коренем аорти <40 мм рекомендовано проводити вагінальні пологи [6]. Якщо діаметр висхідної аорти становить 40-45 мм, рекомендовано вагінальні пологи із прискореною другою фразою та регіональною анестезією для запобігання пікам AT, що може викликати розшарування. Також може розглядатися проведення кесаревого розтину у вагітних із діаметром кореня аорти >45 мм, виходячи з індивідуальної ситуації $[6,8]$.

Жінки із СМ мають підвищений ризик розшарування протягом принаймні 6 місяців після пологів, проте деякі дослідження зазначають, що цей ризик може залишатися підвищеним принаймні протягом 1 року після пологів [8].

Katherine Smith та Bernard Gros [8] провели огляд літератури щодо випадків вагітності у жінок із СМ з 1981 до 2015 року. Всього в 12 повідомленнях було оцінено перебіг 1271 вагітності у 832 жінок із СМ. 39 цих вагітностей були ускладнені гострим розшаруванням аневризми аорти (ГРАА). Отже, ризик виникнення ГРАА у вагітних жінок із СМ склав 3,07 \%. Але ця оцінка не враховує таких фракторів, як використання бета-блокаторів, профрілактичну корекцію аневризми аорти та вихідного розміру кореня аорти. Із цих причин справжній ризик розвитку ГРАА під час вагітності для жінок із СМ може бути значно більшим, особливо для пацієнток із дилатацією кореня аорти [8]. Відповідно до критеріїв, автори провели аналіз 36 випадків ГРАА у жінок із СМ та порівняли їх із 36 випадками ГРАА у безсиндромних пацієнток (табл. 3).

Отже, аналізуючи проведене дослідження, можна відзначати такі особливості вагітності при СМ:

- ГРАА при СМ може розвиватися при незначному збільшенні діаметра кореня аорти, а в деяких випадках і при нормальних розмірах кореня. У більшості випадків це - тип А ГРАА;

- ГРАА, як правило, спостерігається у III триместрі вагітності, хоча при СМ це може відбуватися у будь-якому терміні гестації, протягом раннього післяпологового періоду або всі 12 місяців після пологів;

- материнські та фретальні втрати при ГРАА є значними як у жінок із СМ, так і у безсиндромних пацієнток;

- досвід проведення оперативних втручань на аорті при її розшаруванні з fetus in utero $€$ обмеженим.

ВисновКИ. 1. Наявність синдрому Марфана значно збільшує материнські та перинатальні ризики. 
Акушерство та гінекологія

Таблиця 3. Порівняльний аналіз випадків ГРАА у вагітних жінок із СМ та у безсиндромних вагітних [5]

\begin{tabular}{|c|c|c|}
\hline Параметр & $\begin{array}{c}\text { ГPAA i3 CM } \\
(n=36)\end{array}$ & $\begin{array}{c}\text { ГРАА без СМ } \\
(n=36)\end{array}$ \\
\hline Тип А ГРАА & 26 & 27 \\
\hline Тип В ГРАА & 10 & 9 \\
\hline Діаметр кореня аорти (середнє), мм & $51,72 \pm 15,66$ & $45,17 \pm 5,79$ \\
\hline \multicolumn{3}{|l|}{ Час дисекції } \\
\hline \multicolumn{3}{|l|}{ I триместр (до 12 тижня гестації) } \\
\hline Тип А ГРАА & 2 & 0 \\
\hline Тип В ГРАА & 0 & 0 \\
\hline \multicolumn{3}{|l|}{ II триместр (13-27 тиждень гестації) } \\
\hline Тип А ГРАА & 5 & 0 \\
\hline Тип В ГРАА & 3 & 1 \\
\hline \multicolumn{3}{|l|}{ III триместр (після 28 тижня гестації) } \\
\hline Тип А ГРАА & 13 & 19 \\
\hline Тип В ГРАА & 5 & 3 \\
\hline \multicolumn{3}{|c|}{ Післяпологовий період (до 12 місяців після пологів) } \\
\hline Тип А ГРАА & 6 & 8 \\
\hline Тип В ГРАА & 2 & 5 \\
\hline \multicolumn{3}{|l|}{ Способи розродження, \% } \\
\hline Кесаревий розтин & 72,2 & 80,0 \\
\hline Вагінальні пологи & 22,2 & 14,3 \\
\hline Материнська летальність, \% & 20,6 & 22,2 \\
\hline Перинатальні втрати, \% & 11,7 & 11,7 \\
\hline Втручання на аорті з fetus in utero, $n$ & 2 & 2 \\
\hline
\end{tabular}

Ризик розвитку ГРАА у пацієнток із СМ під час вагітності складає від 1 до 10 \% та залежить від вихідного діаметра аорти.

2. Вагітніти не рекомендовано пацієнткам із значною дилатацією висхідної аорти (>45 мм) та синдромом Марфрана, але це питання залишається контраверсійним.

3. Преконцепційне консультування з виявленням факторів ризику та предгравідарна підготовка (в тому числі із проведенням профрілактичної хірургії) $€$ наріжним каменем первинної профрілактики материнської смертності внаслідок ГРАА. Вторинна профілактика виникнення великих кардіальних подій у вагітних із СМ полягає у жорсткому динамічному контролі АТ та розмірів висхідної аорти протягом вагітності та 12 місяців після родорозрішення.

4. Превентивне хірургічне втручання на аорті при СМ варто розглядати протягом вагітності при діаметрі висхідної аорти понад 45 мм та при зростанні діаметра протягом вагітності. Профрілактичну хірургію аорти у вагітної варто розглянути у II триместрі вагітності.

5. Медичний супровід вагітних із СМ протягом всієї вагітності має проводитись мультидисциплінарною командою фахівців з урахуванням сучасних рекомендацій та досвіду команди.

6. Вагітним із коренем аорти <40 мм та СМ рекомендовано проводити вагінальні пологи. Якщо діаметр висхідної аорти становить 40-45 мм, рекомендовано вагінальні пологи із прискореною другою фразою та регіональною анестезією. Кесаревий розтин також може розглядатися у вагітних із діаметром кореня аорти >45 мм, виходячи 3 індивідуальної ситуації.

ПЕРСПЕКТИВИ ПОДАЛЬШИХ ДОСЛІДЖЕНЬ. ПрОблематиці медичного супроводу вагітних та породілей із СМ присвячено велику кількість досліджень. Втім, досі немає згоди експертів за деякими важливими нюансами. Чи варто жінці із СМ та аортопатією взагалі вагітніти? На сьогодні європейські настанови вагітніти в такому випадку не рекомендують. Але і клас рекомендацій (III) та ступінь доказовості (C) - найнижчі, а отже, потребують подальшого вивчення [6]. Дослідження 3 цього питання (ROPAC) проводить міжнародна група експертів під егідою Європейського товариства кардіологів. Якими є фрактори ризику виникнення ГРАА під час вагітності у пацієнток із СМ? Якими є показання до проведення превентивного хірургічного втручання на аорті у пацієнток із СМ, що планують вагітніти? Яка має бути тактика лікаря при встановленні діагнозу СЗГА (в т. ч. СМ) з аортопатією під час вагітності? Які оптимальні параметри проведення штучного кровообігу мають бути при операції з fetus in utero? I нарешті, який вид родорозрішення показаний таким пацієнткам? Всі ці питання тепер активно обговорюються в експертному середовищі й потребують подальших практичних і теоретичних досліджень та обґрунтувань. 


\section{СПИСОК ЛІТЕРАТУРИ}

1. Сіромаха С. О. Орфанні спадкові захворювання грудної аорти та вагітність. Сучасні уявлення та рекомендації / С. О. Сіромаха // Український журнал серцево-судинної xipypriï. - 2020. - № 2 (39). - C. 69-74.

2. Byers P. H. Vascular Ehlers-Danlos Syndrome / P. H. Byers ; in Adam M. P., Ardinger H. H., Pagon R. A. [et al.] editors. Seattle (WA): University of Washington, Seattle, 1993-2020. - Access mode : https://www.ncbi.nlm.nih.gov/ books/NBK1494/

3. Milewicz D. M. Heritable thoracic aortic disease overview / D. M. Milewicz, E. Regalado; in Adam M. P., Ardinger H. H., Pagon R. A. [et al.] editors. Seattle (WA): University of Washington, Seattle; 1993-2020. Access mode : https://www. ncbi.nlm.nih.gov/books/NBK1120/

4. Hecht F. "New" syndrome of congenital contractural arachnodactyly originally described by Marfan in 1896 / F. Hecht, R. K. Beals // Pediatrics. - 1972. - Vol. 49 (4). - P. 574-579.

5. The Marfan syndrome locus: confirmation of assignment to chromosome 15 and identification of tightly linked markers at 15q15-q21.3 / H. C. Dietz, R. E. Pyeritz, B. D. Hall [et al.] // Genomics. - 1991. - Vol. 9 (2). - P. 355-361.

6. 2018 ESC Guidelines for the management of cardiovascular diseases during pregnancy / V. Regitz-Zagrosek, J.W. RoosHesselink, J. Bauersachs [et al.] // European Heart Journal. - 2018. - Vol. 39 (34). - P. 3165-3241.

7. Жураєв Р. К. Синдром Марфана: еволюція діагностичних критеріїв / Р. К. Жураєв // Український медичний часопис. - 2012. - № 1 (87). - C. 98-102.

8. Smith K. Pregnancy-related acute aortic dissection in Marfan syndrome: A review of the literature / K. Smith, B. Gros // Congenital heart disease. - 2017. - Vol. 12 (3). - P. 251-260.

9. ESC Guidelines on the management of cardiovascular diseases during pregnancy: the Task Force on the Management of Cardiovascular Diseases during Pregnancy of the European Society of Cardiology (ESC) / V. Regitz-Zagrosek, C. Blomstrom Lundqvis, C. Borghi [et al.] // European Heart Journal. - 2011. - Vol. 32 (24). - P. 3147-3197.

10. Патент України на корисну модель 107516. Спосіб кардіохірургічної та акушерської допомоги жінкам з синдромом Марфана / В. В. Лазоришинець, Ю. В. Давидова, А. Ю. Лиманська, В. І. Кравченко, К. В. Руденко, С. О. Сіромаха, О. А. Крикунов, О. О. Ревенько. - 2016.

11. Патент України на корисну модель 129560. Спосіб моніторування стану плоду під час операції на серці матері зі штучним кровообігом / С. О. Сіромаха, Ю. В. Давидова, В. В. Лазоришинець. -2018.

12. Possible extracardiac predictors of aortic dissection in Marfan syndrome / B. Agg, K. Benke, B. Szilveszter [et al.] // BMC cardiovascular disorders. - 2014. - Vol. 14 (47).

13. High-risk cardiac disease in pregnancy: Part I / U. Elkayam, S. Goland, P. G. Pieper, C. K. Silverside // Journal of the American College of Cardiology. - 2016. - Vol. 68 (4). - P. 396-410.

14. Barrett J. M. Pregnancy-related rupture of arterial aneurysms / J. M. Barrett, J. E. Van Hooydonk, F. H. Boehm // Obstetrical \& Gynecological Survey. - 1982. - Vol. 37 (9). - P. 557-566.

15. Jovanović S. Remodelling of guinea-pig aorta during pregnancy: selective alteration of endothelial cells / S. Jovanović, A. Jovanović // Human Reproduction (Oxford, England). - 1997. - Vol. 12 (10). - P. 2297-2302.

16. Stock S. Plasma levels of oxytocin during the menstrual cycle, pregnancy and following treatment with HMG / S. Stock, K. Bremme, K. Uvnäs-Moberg // Human Reproduction (Oxford, England). - 1991. - Vol. 6 (8). - P. 1056-1062.

17. Biophysical properties of the normal-sized aorta in patients with Marfan syndrome: evaluation with MR flow mapping / M. Groenink, A. de Roos, B. J. Mulder [et al.] // Radiology. 2001. - Vol. 219 (2). - P. 535-540.

18. Aortic dissection in pregnancy: analysis of risk factors and outcome / F. F. Immer, A. G. Bansi, A. S. Immer-Bansi [et al.] // The Annals of Thoracic Surgery. - 2003. - Vol. 76 (1). P. 309-314.

19. Phornphutkul C. Cardiac manifestations of Marfan syndrome in infancy and childhood / C. Phornphutkul, A. Rosenthal, A. S. Nadas // Circulation. - 1973. - Vol. 47 (3). - P. 587-596.

20. Causes and histopathology of ascending aortic disease in children and young adults / J. D. Dietz, H. C. Oswald, G. L. Maleszewski [et al.] // Cardiovascular Pathology: The Official Journal of the Society for Cardiovascular Pathology. 2011. - Vol. 20 (1). - P. 15-25.

21. Pregnancy and aortic root growth in the Marfan syndrome: a prospective study / L. J. Meijboom, F. E. Vos, J. Timmermans [et al.] // European Heart Journal. - 2005. Vol. 26 (9). - P. 914-920.

22. The immediate and long-term impact of pregnancy on aortic growth rate and mortality in women with Marfan syndrome / R. T. Donnelly, N. M. Pinto, I. Kocolas, A. T. Yetman // Journal of the American College of Cardiology. - 2012. - Vol. 60 (3). P. 224-229.

23. 2010 ACCF/AHA/AATS/ACR/ASA/SCA/SCAI/ SIR/ STS/SVM guidelines for the diagnosis and management of patients with thoracic aortic disease: a report of the American College of Cardiology Foundation/American Heart Association Task Force on Practice Guidelines, American Association for Thoracic Surgery, American College of Radiology, American Stroke Association, Society of Cardiovascular Anesthesiologists, Society for Cardiovascular Angiography and Interventions, Society of Interventional Radiology, Society of Thoracic Surgeons, and Society for Vascular Medicine / L. F. Hiratzka, G. L. Bakris, J. A. Beckman [et al.] // Circulation. - 2010. Vol. 121 (13). - P. e266-e369.

\section{REFERENCES}

1. Siromakha, S.O. (2020). Orfanni spadkovi zakhvoriuvannia hrudnoi aorty ta vahitnist. Suchasni uiavlennia ta rekomendatsi [Orphan heritable thoracic aortic diseases and pregnancy. modern outlooks and guidance]. Ukrainskyi zhurnal sertsevosudynnoi khirurhii - Ukrainian Journal of Cardiovascular Surgery, 2 (39), 69-74 [in Ukrainian].

2. Byers, P.H. (2019). Vascular Ehlers-Danlos Syndrome. Adam, M.P., Ardinger, H.H., Pagon, R.A. (Eds.). Seattle (WA): University of Washington, Seattle; 1993-2020. Retrieved from: https://www.ncbi. nlm.nih.gov/books/NBK1494/
3. Milewicz, D.M., \& Regalado, E. (2020). Heritable thoracic aortic disease overview. Adam, M.P., Ardinger, H.H., \& Pagon, R.A. (Eds.) Seattle (WA): University of Washington, Seattle; 1993-2020. Retrieved from: https://www.ncbi.nlm.nih.gov/books/ NBK1120/

4. Hecht, F., \& Beals, R.K. (1972). "New" syndrome of congenital contractural arachnodactyly originally described by Marfan in 1896. Pediatrics, 49 (4), 574-579.

5. Dietz, H.C., Pyeritz, R.E., Hall, B.D., Cadle, R.G., Hamosh, A., Schwartz, J., ... \& Francomano, C.A. (1991). The Marfan 
syndrome locus: confirmation of assignment to chromosome 15 and identification of tightly linked markers at 15q15-q21.3. Genomics, 9 (2), 355-361.

6. Regitz-Zagrosek, V., Roos-Hesselink, J.W., Bauersachs, J., Blomström-Lundqvist, C., Cífková, R., De Bonis, M., ..., \& Warnes, C.A. (2018). 2018 ESC Guidelines for the management of cardiovascular diseases during pregnancy. European Heart Journal, 39 (34), 3165-3241.

7. Zhurayev, R.K. (2012). Syndrom Marfana: evolyutsiia diahnostychnykh kryteriiv [Marfan's syndrome: evolution of diagnostic criteria]. Ukrainskyi medychnyi chasopys - Ukrainian Medical Journal, 1 (87), 98-102 [in Ukrainian].

8. Smith, K., \& Gros, B. (2017). Pregnancy-related acute aortic dissection in Marfan syndrome: A review of the literature. Congenital Heart Disease, 12 (3), 251-260.

9. Regitz-Zagrosek, V., Blomstrom Lundqvist, C., Borghi, C., Cifkova, R., Ferreira, R., Foidart, J.M., ..., \& Warnes, C. (2011). ESC Guidelines on the management of cardiovascular diseases during pregnancy: the Task Force on the Management of Cardiovascular Diseases during Pregnancy of the European Society of Cardiology (ESC). European Heart Journal, 32 (24), 3147-3197.

10. Lazoryshynets, V.V., Davydova, Yu.V., Lymanska, A.Yu., Kravchenko, V.I., Rudenko, K.V., Siromakha, S.O., ..., \& Revenko, O.O. (2016). Sposib kardiokhirurhichnoi ta akusherskoi dopomohy zhinkam z syndromom Marfana [Method of obstetrics and cardiac surgery aid for women with Marfan syndrome] Patent of Ukraine 107516 [in Ukrainian].

11. Siromakha, S.O., Davy`dova, Yu.V., \& Lazoryshynets, V.V. (2018). Sposib monitoruvannia stanu plodu pid chas operatsii na sertsi materi zi shtuchnym krovoobihom [A method of monitoring the condition of the fetus during surgery on the mother's heart with extracorporal circulation]. Patent of Ukraine 129560 [in Ukrainian].

12. Agg, B., Benke, K., Szilveszter, B., Pólos, M., Daróczi, L., Odler, B., ..., \& Szabolcs, Z. (2014). Possible extracardiac predictors of aortic dissection in Marfan syndrome. BMC Cardiovascular Disorders, 14 (47).

13. Elkayam, U., Goland, S., Pieper, P.G., \& Silverside, C.K. (2016). High-risk cardiac disease in pregnancy: Part I. Journal of the American College of Cardiology, 68 (4), 396-410.

14. Barrett, J.M., Van Hooydonk, J.E., \& Boehm, F.H. (1982). Pregnancy-related rupture of arterial aneurysms. Obstetrical \& Gynecological Survey, 37 (9), 557-566.
15. Jovanović, S., \& Jovanović, A. (1997). Remodelling of guinea-pig aorta during pregnancy: selective alteration of endothelial cells. Human Reproduction (Oxford, England), 12 (10), 2297-2302.

16. Stock, S., Bremme, K., \& Uvnäs-Moberg, K. (1991). Plasma levels of oxytocin during the menstrual cycle, pregnancy and following treatment with HMG. Human Reproduction (Oxford, England), 6 (8), 1056-1062.

17. Groenink, M., de Roos, A., Mulder, B.J., Verbeeten, B., Jr, Timmermans, J., Zwinderman, A. H., ..., \& van der Wall, E.E. (2001). Biophysical properties of the normal-sized aorta in patients with Marfan syndrome: evaluation with MR flow mapping. Radiology, 219 (2), 535-540.

18. Immer, F.F., Bansi, A.G., Immer-Bansi, A.S., McDougall, J., Zehr, K.J., Schaff, H.V., \& Carrel, T.P. (2003). Aortic dissection in pregnancy: analysis of risk factors and outcome. The Annals of Thoracic Surgery, 76 (1), 309-314.

19. Phornphutkul, C., Rosenthal, A., \& Nadas, A.S. (1973). Cardiac manifestations of Marfan syndrome in infancy and childhood. Circulation, 47 (3), 587-596.

20. Jain, D., Dietz, H.C., Oswald, G.L., Maleszewski, J.J. \& Halushka, M.K. (2011). Causes and histopathology of ascending aortic disease in children and young adults. Cardiovascular pathology : the official journal of the Society for Cardiovascular Pathology, 20 (1), 15-25.21. Meijboom, L.J., Vos, F.E., Timmermans, J., Boers, G.H., Zwinderman, A.H., \& Mulder, B.J. (2005). Pregnancy and aortic root growth in the Marfan syndrome: a prospective study. European Heart Journal, 26 (9), 914-920.

22. Donnelly, R.T., Pinto, N.M., Kocolas, I., \& Yetman, A.T. (2012). The immediate and long-term impact of pregnancy on aortic growth rate and mortality in women with Marfan syndrome. Journal of the American College of Cardiology, 60 (3), 224-229.

23. Hiratzka, L.F., Bakris, G.L., Beckman, J.A., Bersin, R.M., Carr, V.F., Casey, ..., \& Williams, D.M. (2010). 2010 ACCF/ AHA/AATS/ACR/ASA/SCA/SCAI/ SIR/ STS/SVM guidelines for the diagnosis and management of patients with Thoracic Aortic Disease: a report of the American College of Cardiology Foundation/American Heart Association Task Force on Practice Guidelines, American Association for Thoracic Surgery, American College of Radiology, American Stroke Association, Society of Cardiovascular Anesthesiologists, Society for Cardiovascular Angiography and Interventions, Society of Interventional Radiology, Society of Thoracic Surgeons, and Society for Vascular Medicine. Circulation, 121 (13), e266-e369.

Отримано 15.05.20

Прийнято до друку 16.06.20

Електронна адреса для листування: newsersir@gmail.com 